Simon Bulmer and Martin Burch

\title{
THE EUROPEANIZATION OF UK GOVERNMENT: FROM QUIET REVOLUTION TO EXPLICIT STEP- CHANGE?
}

\author{
Simon Bulmer \\ Department of Government \\ University of Manchester \\ Manchester M13 9PL \\ Simon.bulmer@man.ac.uk \\ Tel: 0161-275-4890 \\ Martin Burch \\ Department of Government \\ University of Manchester \\ Manchester M13 9PL \\ Martin.burch@man.ac.uk \\ Tel: 0161-275-4903
}

Paper presented at UACES/ESRC Seminar on Europeanisation

Department of Politics

University of Sheffield

$19^{\text {th }}$ September 2003

Draft only. Please do not quote without the express permission of the authors 


\title{
THE EUROPEANIZATION OF UK GOVERNMENT: FROA QUIET REVOLUTION TO EXPLICIT STEP-CHANGE?
}

\author{
Simon Bulmer and Martin Burch
}

The adaptation of UK government to European integration has been a long-term process. It can be dated back to the 1961 application by the Conservative government under Harold Macmillan to join the European Communities. The process developed in earnest after the UK's accession in 1973. However, accession was not a "big-bang" event, since adjustment had begun before accession, and the EU of today has developed massively compared to the European Communities (EC) of 1973. The process since 1973 was an incremental one characterised by a broadening of policy coverage and increasing institutional density at European level. Occasional high-profile debates, such as those at the time of the 1975 UK referendum on continued membership or during the ratification of the Maastricht Treaty, highlighted the importance of the European issue. However, away from these periods of wider public attention, the impact of integration upon UK government and the policy process developed incrementally in a relatively unseen manner. The cumulative effect of these changes, however, amounted to a substantial and significant alteration in the pattern of UK government and policy-making. Thus, over time a transformation of British government took place that could be regarded as a quiet revolution.

The election of the Blair government in 1997, and its re-election with a second landslide majority in 2001, brought the process of "adapting to Europe" sharply into focus for three key reasons. First, Blair's 1997 manifesto contained a commitment to conducting a constructive policy within the European Union (EU). Blair wished to bring about a "stepchange" in the UK's relationship with its EU partners. Secondly, it also included reforms to institutions in Westminster and Whitehall that would bear upon the domestic pattern of EU policy-making. Thirdly, his programme of devolving power to authorities in Scotland, Wales, Northern Ireland and London represented a major departure from the predominantly centralised machinery of government that had structured the UK's diplomatic and administrative response to EU membership theretofore. Legislation for English regional devolution has been introduced in Blair's second term, and is likely to reinforce this new direction. If these developments are not sufficient to contend with, the separate ones under way at supranational level mean that UK adaptation is taking place within a fluid EU context: ratification of the 1997 Amsterdam Treaty; agreement on the Nice Treaty; the introduction of the euro in 2002 (but not in the UK); enlargement of the EU in May 2004 to accommodate 10 new member states; and a constitutional convention (in 2002-3) that was designed to pave the way for a fundamental overhaul of the EU's institutions to cope with a membership of 25 or more member states.

In this paper we review - from a UK perspective - how the UK government and its policy process have adapted to European integration. Has adaptation been a quiet revolution, a step-change, or both? In exploring this puzzle we draw upon the conceptual literature of Europeanisation. We employ it to shed light on the longer-term pattern of UK adaptation 
as well as to put into context the domestic changes currently under way. Although commentators frequently alight upon continued non-membership of the euro as an indicator of the UK's continued incomplete adaptation to integration, we argue that there is a step-change under way in the Europeanisation of UK EU policy making, though not necessarily in its outcomes.

\section{THE EUROPEANIZATION OF UK GOVERNMENT}

The literature on Europeanisation has been growing in recent times and is moving towards more explicit attempts both to define the concept and to set out research designs for exploring its empirical features (Börzel 1999; Risse, Cowles and Caporaso 2001; Radaelli 2000; Featherstone and Radaelli 2003; Knill 2001). At a general level Europeanisation concentrates on the impact of the EU upon the member states, something which might more accurately be defined as "EU-ization" (Wallace, 2001). Clearly, there are different component parts of the political system which are affected in this way: the polity, political forces, the political economy and policy content. In this paper we focus on the executive branch of government in the UK and indirectly the UK policy process.

In focusing on the Europeanisation of the polity, i.e. of domestic governance structures, it is easier to isolate the causation flowing from the EU than is the case with policy studies. In the case of the latter Europeanisation in some instances may turn out not to be an independent variable at all. It may simply be mediating underlying developments with their origins in global economic transformation or be constructed discursively in order to make globalization more palatable domestically (see Hay and Rosamond 2002). But it is still not easy to isolate causation in the Europeanisation of the polity. One of the problems is the fact that the "object" - in this case UK executive government - has not been static. Indeed, over the period of nearly half a century that we are concerned with in this paper, there have been many changes that have been quite unrelated to Europe. Individual governments have reconstructed Whitehall ministries, direct rule was introduced in Northern Ireland, new public management techniques have been introduced, and reforms under Blair such as devolution: all of these have meant that it has been a shifting UK landscape that has been subject to a Europeanisation effect.

This problem becomes particularly acute under the Blair government, since there have been three sets of development that are difficult to disentangle. First, the pace of reform and change within the EU has accelerated: so far two sets of treaty reform, another under way, plus the largest enlargement in the history of integration. Second, the Blair government has sought to increase its engagement with partner states in the EU. Third, domestically the constitution has been subject to multiple reforms. These encompass devolution to Scotland, Wales and, with intermittent suspensions, Northern Ireland; English devolution, including to the Greater London Authority; independence for the Bank of England; electoral reform (the use of proportional representation for certain elections, notably in devolved authorities and for the European Parliament); incorporation of the European Convention on Human Rights (ECHR); reform of the House of Lords; modernisation of the House of Commons; and the introduction of a Freedom of 
Information Act. Of these devolution resonates with the emergence of multi-level governance in the EU; the member states have been enjoined to introduce a common electoral system for European elections, Bank of England independence fulfilled a requirement for a later step to joining the euro, and the ECHR is a European construct, even if it falls under the Council of Europe in Strasbourg rather than being part of the EU itself.

How does this problem of attributing causality tie in with contemporary frameworks for the analysis of Europeanisation? There is no absolute solution to this problem. Circumspection is needed so as not to attribute all change to Europeanisation. At the same time care needs to be taken with conceptual definition. Taking definitional issues first, we adapt a definition from Bulmer and Radaelli (2004 forthcoming) and understand Europeanisation as follows:

Europeanisation consists of processes of a) construction, b) diffusion and c) institutionalisation of formal and informal rules, procedures, policy paradigms, styles, "ways of doing things" and shared beliefs and norms which are defined and consolidated in the EU policy process and incorporated in the logic of domestic (national and subnational) discourse, political structures and public policies.

One view of Europeanisation associates domestic adjustment with some kind of "misfit" with the EU (see Börzel 1999; Risse, Cowles and Caporaso 2001). However, "misfit" does not represent a "necessary condition for domestic change" (Knill 2001: 13). For example, Héritier and Knill have found cases of domestic reforms taking place despite an absence of misfit (Héritier and Knill 2001). Haverland (2000) has drawn attention to the importance of institutional veto points in explaining the adjustment to adaptation pressures. According to his emphasis it is not just misfit but the presence/absence of veto points that explains the mechanisms of Europeanisation. These analytical observations suggest that Europeanisation is subtle and differentiated. Indeed, in terms of policy adaptation Bulmer and Radaelli (2004 forthcoming) have suggested that there are different "default" mechanisms of Europeanisation, depending on the mode of governance prevailing in the EU policy issue under the spotlight.

Some of the above concerns are less relevant to the Europeanisation of the national polity as opposed to of national policy. Nevertheless, we find merit in the broad framework developed by Risse, Cowles and Caporaso (2001) and return to it shortly. Before doing so, we identify some analytical issues that will feature in the empirical part of the paper.

First, although we are concerned with the top-down impact of the EU upon the member state, the definition used above identifies the explicitly interactive nature of Europeanisation. In other words, we recognise that there is an iterative process under way, not least because the adaptation of the UK governmental system is designed in part to ensure effective input into EU policy-making in Brussels. Thus we see adjustment to the EU as a process of aligning two institutional logics: that of the EU and that of UK governance. This adjustment process entails two separate steps. As a first and necessary stage domestic institutions must find suitable ways of processing EU business. The 
lowest adjustment cost is incurred by incorporating EU business into the pre-existing domestic logic of governance through some switching mechanism. However, domestic institutions must also adapt their procedures so as to be able to make an effective contribution to those EU dynamics. We term these two components of institutional response to Europeanisation "reception" and "projection" (Bulmer and Burch 2000 and 2002). "Reception" involves a much larger part of UK government because so much of British policy has a European dimension. To take a concrete example, the Department for the Environment, Food and Rural Affairs (DEFRA) is subject to a wide range of EU policy: on the environment, food standards, agriculture and fisheries. But whilst a large part of the ministry's organisation and officials is working within guidelines set by the EU, a rather smaller subset is engaged in the projection side, i.e. formulating UK input into proposed legislation or other decisions. Looking at the impact of the EU more broadly, it is worth drawing attention to a study conducted by Ed Page (1998). In an analysis of UK Statutory Instruments (SIs) over the period 1987-97 he found that 15.8 per cent could be traced to European legislation. Page concluded that this figure was still a relatively modest proportion, although it displayed considerable variation; 51.3 per cent of SIs issued by the (then) Ministry of Agriculture Fisheries and Food (MAFF) could be traced to EU legislation.

Page was concerned with Europeanisation as "reception". We argue that "reception" is a first response to Europeanisation. It is a prior step to the "projection" response. "Projection" refers to the development of machinery for securing an effective voice in the formulation of policy in Brussels. It means learning the rules of the game in Brussels, and they may be different from those in the domestic political system.

A third response to Europeanisation is to regard it as an opportunity structure for resolving domestic policy problems that are perceived not to be properly resolved within a national context, e.g. because their scale goes beyond that of the nation state. This third response involves making systematic use of the "projection" response in order to make an imprint on the activities of the EU.

Whilst this paper is concerned with "political structures" we should note that they are bound up with other aspects of Europeanisation mentioned in the definition. The partypolitical sensitivity of European policy for much of the period since 1973, such as over the issue of sovereignty, has had an impact upon the ability of UK policy-makers to utilise the EU as an opportunity structure. UK discourse surrounding European integration - whether articulated in a rather sceptical print media (Wring in Baker and Seawright 1998) or in the parliamentary arena - has scarcely helped the active engagement with the EU that is implied in the third response outlined above.

How, then, do we summarise our understanding of Europeanisation and domestic institutional change? We set this out in Figure 1, which adapts the work of Risse, Cowles and Caporaso (2001). In this simple model adaptation pressure derives from the EU level and prompts adjustment of domestic institutional design. Domestic institutions, together with the cultures and norms within them, are important mediators of adaptation pressure. Their stickiness in responding to change is well understood in the term "path- 
dependency" (Pierson 1996). Institutional veto points may inhibit change, although the UK political system is generally regarded as less subject to them than the more pluralist patterns of, say, Germany. Entrenched political beliefs and/or institutional cultures may also form barriers to adaptation. However, the importance of agency is also recognised: that is, actors responding to the domestic institutional context. These actors may as easily seize the opportunity offered by EU pressures to effect domestic structural changes. Exceptions to path-dependency do occur. In any event, the dependent variable of the model of adaptation is domestic institutional change.

\section{(SEE FIGURE 1)}

In what follows we examine how UK central government has adapted to pressures emanating from European integration in the period up to 1997. We then explore the record of adaptation under Blair. In exploring these two phases we use the categories set out in Figure 1. Our explanation therefore zeroes in on the institutional mediating factors at domestic level.

- Changes in formal authority and institutional veto points. How far has European integration brought about changes such as these?

- Changes in institutional opportunity structures, especially in information-sharing, policy-making and decision-taking networks (which may be expected to vary across policy areas). What new opportunity structures have been opened up by the EU for UK government?

- Changes in political and organisational cultures. Has Europeanisation led to change in the political and organisational cultures of UK government?

- Changes in key actors and the responses of existing political actors in exploiting the new institutional environment. How have political actors sought to exploit the UK's Europeanisation?

\section{THE ADAPTATION OF UK GOVERNMENT - THE STORY PRIOR TO 1997}

UK government commenced its response to Europeanisation ahead of accession in 1973. Indeed, as has been argued elsewhere, the broad framework of the response emerged at the time of the negotiations for entry in 1961 (Bulmer and Burch 1998: 608-9). The basic principles of the response were wholly in keeping with traditional ways of working in Whitehall. They comprised the following key features:

- delegating the detailed consideration of substantive policy to the relevant UK ministry;

- assigning diplomatic functions to the Foreign Office;

- identifying the important legal dimension to integration, and placing it under the authority of the Treasury Solicitor's Office;

- ensuring that policy was co-ordinated effectively within Whitehall through reliance on traditional cabinet mechanisms (a Cabinet committee underpinned by committees of officials); and

- the emergence of a set of core ministries at the heart of Europeanisation, with an outer tier having more intermittent involvement. 


\section{The core ministries}

With accession in 1973 the core group of ministries was clear. This group comprised those ministries which had to respond to the policy impacts of Europeanisation as well as by participating in the formulation of the UK government's input into the EC. A review of possible co-ordination options during 1971 had considered options, including the highly centralised French system of co-ordination (the SGCI) based around the French prime minister's office as well as the possibility of a Ministry for Europe (see Wallace and Wallace 1973: 254). The three key departments - the Foreign and Commonwealth Office (FCO), the Cabinet Office and the Treasury seemed to reach agreement relatively easily. At the political level Prime Minister Edward Heath took the view that there should not be a Ministry for Europe but, rather, departments should think and act European and set up machinery to that end (Bulmer and Burch 1998: 612).

At the time of accession the principal ministries affected by substantive EU policy were MAFF, the Treasury, the Department of Trade and Industry (DTI), the FCO and Customs and Excise. Legal advisors in the Treasury Solicitor's Department oversaw the transposition of EC legislation across Whitehall. This centralised function was designed to ensure that departments undertook their duties to transpose EC legislation. Regarded as a being a branch of the Cabinet Office - complete with an official-level cabinet committee to oversee matters - this arrangement explains why adapting to Europe has involved a good UK record at transposing European legislation despite the party-political trials and tribulations associated with integration.

The co-ordination of European policy-making - i.e. "projection" of policy in Brussels as well as a measure of general oversight was achieved through a small central secretariat in the Cabinet Office (the European Secretariat). Its three or four top personnel plus legal advisers along with key players in the Prime Minister's Office (PMO) and Foreign and Commonwealth Office (FCO) and the UK's Permanent Representative to the European Communities formed the hub of the government's European policy making network. These personnel, both ministerial and official, plus one or two others from the Treasury and the two Departments most consistently and substantially involved in European matters, dealing with agriculture and trade and industry, formed the inner core of the network. Formally speaking co-ordination was achieved through a tiered system of cabinet committees at both ministerial and official levels. This co-ordinating net stretched out into Brussels through the UK Permanent Representation to the EU (UKRep), and engaged as the need arose, depending on the nature of the issue, personnel in other domestic Departments. At first, other than those Departments already mentioned, very few others were involved.

This structure and approach to handling European business was adapted over the period from 1973 largely to take into account the development of EC/EU competencies and the consequent growth of business and the spread of the network to include all central government Departments. However, the principles and the broad framework of operation did not change despite the considerable expansion in EU-related activity. It was simply that new European policies, such as on the environment (see Jordan 2002), necessitated 
the involvement of a widening group of Whitehall officials and ministers in the putting into effect, and shaping, of European policy. The 1993 Maastricht Treaty, with its creation of a "third pillar" to co-ordinate policy on justice and home affairs, had a similar effect. The Home Office joined the group of key players even though the Conservative Government made every effort to resist the Europeanisation of these policy areas. New recruits to "the core" were a function of the development of new policy activities at EU level. Perhaps the most significant of these recruits was the prime minister: this as a result of the inauguration of regular summit meetings (the European Council) in 1975. Key players at ministerial level are thus the Prime Minister and Foreign Secretary, the latter having the lead on EU institutional matters and the chair of the cabinet's ministerial committee on European issues.

How can we come to grips with the changes under way in the core departments, drawing upon the Europeanisation framework that was outlined earlier? A question worth posing at the outset is whether there was any "misfit" between the structure and patterns of UK government and that of the EC/EU. Offering an answer is rather more difficult. There were certainly numerous aspects of supranational governance that did not sit well with British traditions.

- The emergent multi-levelled nature of the EU, with its characteristic sharing of power across tiers, contrasted with the UK's centralised system, where the EU's gain was seen as the UK government's loss.

- The need for alliance building amongst EU governments in the Council contrasted with the majoritarian UK electoral system, where the winner was accustomed to taking all (unless holding only a slender majority in the House of Commons).

- The supremacy of EC law and the possibilities of using qualified majority voting in the Council presented challenges to the UK parliament, with its entrenched notions of sovereignty.

- The roman law of the EU differed from the English common law system.

- The legal-regulatory pattern of the EU differed from the UK's tradition of selfregulation.

- The diffuse network-based pattern of EU governance clashed with the more centralised UK cabinet system.

- The emergent tradition in the EU of having recurrent episodes of institutional reform contrasted with the UK's lack of a domestic constitution and a more pragmatic approach to developing structures of governance according to need rather than grand principles.

This (doubtless incomplete) list would suggest quite a measure of systemic misfit. It certainly contrasts with the greater measure of congruence between the German and EU systems that may, along with other factors, have helped the Federal Republic to enjoy more positive experiences than the UK in its engagement with the EU. And yet relatively few steps were undertaken to bring the UK into closer alignment with the ways of doing things in the EU. The key point here was that there was no specific requirement from the EU that stipulated the development of a better "fit" on the part of domestic institutions. Indeed, any such requirement would have been regarded - in the UK and other member states - as an intrusion into sovereign domestic matters. 
To summarise, there was misfit between the two systems of governance but the need to align was not explicit in the way that often obtains in the Europeanisation of certain policy areas through a duty on the part of member states to transpose EU legislation. How far can this lack of domestic adaptation be attributable to institutional mediating factors at the UK level?

Institutional veto points go a long way to explain the very limited institutional adaptation at domestic level. The UK's centralised system of government, majoritarian rule, parliamentary sovereignty, cabinet system, different constitutional traditions and so on: all represented fundamental traditions in the political system. Why should the UK adjust these features, particularly when the Heath Government had played down the consequences for them of acceding to the EU? If suitable "switching mechanisms" could be found, whereby the adaptation pressures of the EU could simply be accommodated with existing UK governmental structures, why would domestic institutional adaptation be needed at all? In many ways this is precisely what occurred over the first two decades of UK membership. And this approach was bolstered by the recurrent arguments about European integration within and between the main political parties. This background scarcely provided a climate appropriate to reducing misfits with the EU through changes to the long-standing constitutional patterns of the UK.

For quite separate domestic reasons some of the misfits were arguably reinforced. Three examples will suffice:

- The Thatcher Government abolished the metropolitan counties in England and created a more centralised system of territorial power than beforehand. Only with the creation under the Major Government of the government offices in the regions was a small step taken towards the more multi-levelled system encouraged by the EU.

- The Thatcher Government also strengthened the Treasury's control over public expenditure. In line with the shift from expenditure planning to an expenditurecontrol system (see Thain and Wright 1995) a system known as EUROPES was introduced from 1988 to ensure that Whitehall ministries could not subvert the domestic system of control by gaining additional resources from EU funds. The EUROPES system created a default situation whereby the resources obtained by a department from Brussels would simply be deducted from the domestic departmental settlement. Given the greater administrative simplicity of managing purely domestic programmes, EUROPES had the effect of getting spending ministries behind the Treasury's objective of limiting the size of the EU budget (Bulmer and Burch 1998: 618-9). Departments were given an incentive not to engage positively with EU policies that involved spending from the supranational budget.

- A third example relates to the Europeanisation of civil service career structures. Although a cadre of officials and diplomats with considerable experience of the EU was beginning to emerge, some home civil servants found the attractions of a posting in Brussels limited. The management de-layering that many departments underwent in the 1980 s created career uncertainty and a preference to be at "headquarters" rather than face an uncertain re-entry after an EU posting. In this 
case it was central government's embracing of changes associated with the new public management that was responsible.

In each of the above illustrations developments quite separate from European integration had the effect of blocking or exacerbating institutional adaptation to the EU. However, the predominant picture is not one of veto points blocking institutional adaptation to the EU but of small adjustments, designed to "translate" EU needs into compatibility with the existing traditions of UK central government. Thus the handling of EU policy conforms to the basic tenets of the UK state system. This has traditionally been highly centralised and metropolitan with primary and substantial power being placed in the hands of central government in London. Within central government, formally speaking, authority is collective and located within cabinet and its ministerial committees, though in practice authority is both more concentrated and more dispersed than the formal account allows. It all depends on the nature of the issue. Core actors, including the PM and his staff, enjoy substantial authority on issues of high policy or on issues that cannot be settled within or between Departments. Departments and their personnel also enjoy considerable authority in that they lead on policy in their area of responsibility and matters are often settled inside the Department or between the relevant Departments without engaging the wider cabinet system (for a full outline of the nature and origins of the modern cabinet system see Burch and Holliday 1996; Smith 1999).

Over the period since entry, the European co-ordinating machinery for "projection" has operated as a filter on policy and if necessary a means whereby a particular Departmental line could be knocked into shape prior to the business being handled in the EU. It has provided opportunities to intervene in order to ensure that the UK holds back or has an agreed negotiating line. This has been achieved either through the formal structure of committees or more directly through personal contacts by high ranking officials or even by the Prime Minister or Foreign Secretary at ministerial level. An example of this ability to intercede and sort things out is provided by the regular Friday meeting which takes place in the Cabinet Office under the chair of the Head of the European Secretariat, with the UK's Permanent Representative in attendance along with senior officials from the FCO and the Treasury and officials from the Departments whose business is being discussed. The Friday meeting reviews business coming up in the EU in the weeks ahead and the UK line to be pursued. It was certainly used in the early days of membership to bring errant Departments into line. Through such mechanisms the UK has tried to ensure that it is well prepared and "speaks with one voice" in EU fora.

Formally speaking it is ministers, either collectively through cabinet and its committees or individually through their own Departments, who have final authority but officials are highly influential both in shaping and, on occasions, determining policy. Accordingly a key domestic factor that has limited the development of European policy has been party politics. Indeed a central feature in the development of UK European policy is that a relatively efficient, well co-ordinated and smoothly run state machine has throughout been constrained in the actual development and delivery of policy by problems thrown up in the party political sphere. Both before and throughout EC/EU membership Europe has been a source of division in and between the parties (Young 2000). This has greatly 
constrained the activities of ministers especially when the governing party had a small parliamentary majority, as in the case of the second Major administration (1992-97).

Compared with institutional veto points and legacies, opportunity structures have not featured greatly. One important possibility that may be used is for the prime minister to avail him/herself of the opportunities afforded by the European Council to advocate a European policy solution to a domestic problem. In fact this opportunity was little used. However, one clear occasion came in the mid-1980s, when Mrs Thatcher was able to get the single market programme approved by the member states as part of a package that included institutional reform in the Single European Act. A rather different kind of adaptation through exploiting opportunity structures came about with the UK government's decision to set up a European Staffing Unit in the Office of Public Service. The function of this Unit was to encourage the recruitment and training of young graduates into a fast-stream cadre that would take up postings in Brussels. The motivation was that it was important to have a set of able UK officials in the Commission and elsewhere - as distinct from national officials on secondments.

Political actors more widely have availed themselves of new opportunities, but these have typically involved circumventing the UK government to try to obtain better political outcomes. Environmentalist groups, for instance, have taken up their cases in Brussels on whether the UK government had carried out proper environmental impact assessment (Jordan 2002: 181). Large firms have also taken their lobbying direct to Brussels (Fairbrass 2003). However, developments such as these have not led to institutional adaptation on the part of UK central government.

What of political and organisational cultures? The UK approach to handling European business is imbued with certain principles derived from the political and organisational cultures of UK central government. Significant amongst these is the notion of departmental lead on policy, coupled with light monitoring and co-ordination from the centre. The understandings essential to ensuring this system works effectively are those based on an organisational culture of reciprocity and trust. The key practices are those of sharing information and involvement across departments and of informing the centre (that is, in the case of Europe, the Cabinet Office European Secretariat) of matters that are likely to concern it. These practices ensure both a measure of central oversight and the involvement of all those within central government that need to be drawn into discussions. They are backed up by norms of collective decision-making, expressed through conventions such as that of collective responsibility. Overall these principles have contributed to a tendency in the making of European policy to seek agreement "inhouse" in keeping with the consensus across central government. In addition to organisational values, European policy has also been shaped by a general political elite culture of caution when it comes to the public discussion of European issues. Given that Europe has often proved to be divisive, the issue has always posed political management problems for UK governing elites. One response has been to try to keep the issue out of the forefront of public debate which has resulted in a failure of successive governments to address public unease about European policy. The pattern, therefore, has been one of adapting existing ways of doing things rather than major adaptation. 


\section{The outer circle of policy-makers}

Departments outside the core group have been involved in European business in a less intensive manner. Departments responsible for policy areas such as employment, education, social security and the like have been affected by EU policy, to be sure. However, whilst they may have quite important duties to adhere to in respect of EU legislation, they are outliers in terms of "projecting" policy into the Brussels arena. Their participation in the EU policy-making machinery is very much on an "as needed" basis. The so-called territorial departments, which provided central government's presence in Scotland, Wales and Northern Ireland, were each also gradually drawn into the European policy-making network. Their ability to play a significant role was very limited because they were too small in resource terms, too far from the centre, and sometimes neglected. However, they became increasingly active and more assertive in this area of policy from the early 1990s: the Scottish Office in particular (Smith 2001). The government offices in the English regions, set up under the Major government, also became drawn into EU policy (see Burch and Gomez 2002 and 2003). From the point of view of our analytical framework, the picture is very much as for that with "the core".

\section{Summary}

The adaptation of UK central government to integration over the period up to 1997 was principally one of absorbing EU business into the practices established domestically over the last decades. The British constitution, unwritten though it may be, served as a kind of veto point to any adjustment pressures emanating from Brussels. The deadweight of history was supported by an institutional culture that was satisfied with the Whitehall/Westminster machinery. Moreover, given that UK membership had been sold by Edward Heath as having negligible impact on sovereignty, any idea that traditions of British institutions needed alteration would have created an outcry. The fragile support for integration meant that the new institutional opportunity structures that were afforded by engagement in integration were utilised in a very limited manner. Interest groups and large corporations, however, recognised the new realities and sought direct engagement in Brussels to go alongside their established pattern of lobbying in Whitehall. In short, institutional adjustment was limited. But it was widespread. By 1997 every Department had been obliged to invest resources into the monitoring of EU activity. Even Michael Portillo, one of the more Euro-sceptic ministers in the Major Government, found himself unable to escape Europeanisation. As Secretary of State for Defence his Department, as one of the largest landowners, had to contend with EU environmental legislation. Moreover, with civilian personnel employed at military bases in Germany, it found that the Social Chapter of the Maastricht Treaty applied to its activities despite the Conservative Government's opt-out. It was through the many impacts such as these that the business of UK central government may be seen to have undergone a quiet revolution as a result of the EU's impact. But the response to Europeanisation was primarily "reception" then "projection". The utilisation of the EU as an opportunity structure for pursuing British policy goals had only been attempted in respect of the single market programme. 


\section{THE ADAPTATION OF UK GOVERNMENT - POST 1997}

The Blair government has built on established trends in UK/EU policy handling, but it has also set up new structures and processes, which potentially shift the field on which European policy is played out at the domestic level. While these changes have not yet led to significant alterations in outcomes, they have the potential to do so. In general there has been an enhancement of the projection capabilities of UK government and an attempt to get away from a passive and reactive approach to the reception of EU initiatives. More staff and resources, especially at the core, have been devoted to European policy making. In addition there has been an attempt to change the attitude toward the benefits and potentials of the EU project and to mainstream Europe in the activities of all departments. There have also been important changes in the structure of the state, which have required some alteration in the ways in which European policy is made and implemented.

\section{The core ministries}

So far as formal authority and institutional veto points are concerned there has been a significant centralising of EU policy handling at the heart of the core of UK/EU policy process.

Labour in office has benefited from a more benign attitude towards Europe on the part of the governing party than had been the case with their Conservative predecessors. Labour's coming to terms with Europe while in Opposition has allowed them to develop a more up-front, strategic and positive approach to Europe. In order to achieve this more resources and powers of direction have been given to the Centre of the core. In effect there has been a streamlining of effort at the very top through integrating more closely the work of the COES and No 10. The secretariat has, as from August 2000, been substantially augmented. Its personnel have increased from 9 senior officials to $16-$ with four senior staff and 12 desk officers. Its status has been raised through the appointment of Sir Stephen Wall as head of the Secretariat, with the position of Permanent Secretary, and the title of Prime Minister's Adviser on Europe with an office in No10. This has been further complemented by closer connections between the Secretariat and members of the Prime Minister's Policy Unit (PMPU). These connections involve not just the designated EU desk officer in No 10 - Roger Liddle - but others in PMPU who are drawn in not only when their area of specialism has a EU dimension, but also may take part in discussions on the more general aspects of EU policy. The effect of this enhancement of the core has been to give a more executive thrust to policy making and to open up the opportunity for a more directive and strategic approach to European policy making at the very top. It has enhanced the position of the PM and his aides in European policy making.

This more centralised and directive approach to EU policy making in part reflects the style of the Blair administration, but it also reflects longer-term trends towards enhancing the centre of the core which can be traced back to the Callaghan administration (Burch and Holliday 1996). In addition there is a direct EU effect at work here in that there has been increasing requirement for more involvement by heads of government in EU policy making. What the Blair government has done is to build on established trends and to 
significantly extend them. The effect has been to allow for a more centrally focussed and co-ordinated approach to policy making on EU policy in general.

While European policy making is more focussed on the executive and directed from it, there are areas where the re-mit of the Centre is not so tight. A particular feature of the Blair government is the way that executive authority is split between the PM and staff, on the one hand and the Chancellor of the Exchequer and the Treasury on the other. This fault line is one of the central features of the Blair government (Naughtie 2001) and it has had a particular consequence for the economic aspects of European policy. The Treasury still has a somewhat negative effect on European issues through expenditure concerns: notably EUROPES is still in place. But it is in relation to monetary issues that the Treasury has had an impact on the adaptation of the UK to EU pressures through the development and evaluation of the five economic tests required before the government can recommend joining the euro zone. As under the Major government the Treasury has kept charge of the development of policy in relation to the European currency. This factor reflects an important division of authority within UK government and one that has arguably grown more restrictive in the period since 1997.

Turning to changes in institutional opportunity structures, a characteristic feature of the Blair government's approach has been a much more significant effort to realise the potential for affecting the inter-governmental forces and interests which shape EU policies and initiatives. The aim has been to condition the climate of debate surrounding the run-up to key EU decisions through greater contact and liaison at member state level, leading to exchanges of information, alliances on policy initiatives, and long-term coalition building. This approach was enshrined in the so-called "step change" programme from which much else has followed. It grew out of a review, requested by the PM after the UK Presidency in the first half of 1998, of both the substance of UK positions on various policies and the general approach to Europe and how these might be improved. It concentrated on isolating the issues that the UK could take the lead on and the strategy and tactics to be employed. The review recognised the need for the UK to be more positive and pro-active in Europe and thus more able to shape EU agenda setting at an early stage. Closer engagement on European issues with other member states and EU personnel was seen as critical to doing this. The step change project envisaged a ten-year programme for shifting the UK's position on Europe and other member state's perception of it. This networking offensive had two main foci for relationship building. First, between UK ministers and officials and their counterparts in member states. Recognising that formal relations between Germany and France had, since the 1963 Elysee Treaty, been the cornerstone of the development of EC/EU, it was felt that UK needed to similarly court closer ties with partners. This applied to all member states but especially Germany, France, Italy, Spain and the Netherlands as well as the candidate states and particularly Poland as the largest and most significant of these. Initiatives under this programme included regularised Blair/Schroder and Blair/Chirac summits and large set piece meetings to discuss an area of mutual policy interest such as the Anglo-French meeting at St Malo on European defence policy. The second focus of attention was the relationships between ministers and their party contacts on the centre left in Europe. These initiatives were complemented by a project to help shape UK public opinion by 
encouraging more dissemination of information on the EU, counteracting misinformation, and publicly campaigning on EU issues.

Of these initiatives, the contacts with member state personnel were seen as the most important avenue for development. To assist in this activity the Bi-lateral department of the European Union Division in the FCO was created and this took over responsibility for all the member state embassies and diplomatic posts from the West European Department. Thus for the first time all things European were brought within the same command structure. The objective of changing public attitudes involved giving a higher profile and larger campaigning role to the position of Minister of State Europe in the FCO and the creation of a Public Diplomacy Unit in its EU (Internal) department. This unit was also given the task of monitoring the bilateral contacts programme. The whole effort was and is overseen by an inter-departmental committee, MINECOR, chaired by the Minister of State Europe, which draws together all the Departmental ministers responsible for Europe plus the Europe ministers from the devolved administrations. The committee meets about once every six weeks and amongst other matters examines the progress of the bi-lateral contacts programme. It reports directly to the Prime Minister.

The Step Change programme did not address the issue of how best to ensure a strategic approach to Europe. Unlike previous administrations the Blair administration was not deeply divided over Europe so overall European strategy questions could be drawn together at the ministerial level. Initially this seems to have been largely handled through ad hoc meetings involving the Prime Minister and his EU advisers and the Foreign Secretary and other relevant ministers. It was not significantly developed in the Cabinet's European Policy (EP) Committee chaired by the Foreign Secretary. However, the need to prepare for an eventual decision and possible actions on UK's approach to the EURO led to the creation in June 2003 of a cabinet committee on European Strategy (EUS). This is chaired by the Prime Minister and serviced by the Economic and Domestic Affairs Secretariat. Its remit is "to oversee the Government's European strategy, including preparations for UK entry into the single currency, progress on the inter-governmental Conference on the future of Europe and the presentation of the Government's European policy". Of course the committee was also created to draw the EURO policy out of the closed confines of the Treasury and the Chancellor of the Exchequer

Clearly these changes in institutional opportunity structures reflected the internal dynamics of the government. But there was a significant Europeanising effect in the recognition that the UK was failing to fully exploit the opportunities available to it to shape policy at an early stage. This direct Europeanising effect was engaged in primarily to improve the projection side of the UK's approach to Europe.

Labour's more directive, strategic and proactive approach reflected changes in political and organisational cultures which in part enabled these new initiatives to be undertaken and which in part were shaped by them. The most important change was in the attitudes and values of the governing party and its leadership group. Labour was more at ease with the concept of European integration than any government since Heath's in the early 1970s. Labour approach to Europe involved both diagnosis and prognosis. It's perception 
of the UK in Europe over the last thirty years was one of missed opportunities, lack of understanding, a tendency to follow rather than lead, and a cautious and laggardly response to initiatives. Blair summed it up as "hesitation, alienation, incomprehension" with a tendency to "hang-back" and to become a straggler forced to "catch-up" with initiatives pushed forward by others (Blair 2000 and 2002). The outcome was that the UK was often marginalised and isolated in Europe and appeared as a reluctant partner, standing by rather than engaging at the heart of the project. In order to redress this legacy Labour aimed to take a much more active and pro-European approach especially on those issues which it was in the national interest to pursue. On these it was deemed essential that the UK was in the forefront of developing proposals, discussing them with other member state governments, forming alliances and taking the lead. The benefits to all of more active participation were seen as substantial not least because the UK brought something extra to the debate: they offered a bridge between Europe and the USA. This more positive, can-do approach to Europe, was reflected in an emphasis on isolating and persistently pursuing policy matters where UK is able to drive the agenda forward, as in the areas of labour market reform, defence, and asylum. The whole point is to make the best of the UK case by avoiding the usual constraints and trying to shift the action to safer ground where the UK can take the lead or be up-front in the development of policy.

Notably from the very beginning Labour's stance has been somewhat contradictory. It is based on making a more positive play of those matters in keeping with UK interests and potential to act, yet the traditional reluctance to act on many of the key integrationist issues remains below the surface. There is still resistance to any moves towards greater political integration, the single currency remains a problem, and the tradition of divided loyalty between transatlantic ties on the one hand and Europe on the other remains fundamental to the UK stance in Europe. So the shift in political values, while substantial and significant in some areas, has often seemed presentational in others. Nor has the adoption of this more positive, European-aware position been comprehensive across the government. Though no ministers have taken voluble Euro-sceptic positions, not all have been equally enthusiastic. So far as the shift in values is concerned, within the core the Treasury remains problematic. The department had became more EU aware in the mid 1990s, but outside of a small group of European specialists it still tends not to think Europe, or engage very much in Europe. Partly this is explained by the Chancellors dominance of domestic policy at the level of micro detail, leaving less time to for him and his officials to give attention to the European aspects of the Treasury's work. Certainly the Treasury remains is in terms of values and awareness the least Europeanised of the core departments.

So far as administrative culture is concerned there has been one very evident Europeanising effect which has helped to change the guidelines and norms pertaining to the operation of central government in general. Specifically, the adoption of the European Convention of Human Rights into UK law. This has implications for all departments and many aspects of government activity. It has also shifted UK law more in line with continental European law traditions based on codes, principles and legal rights. Conversely it has compromised, at least so far as English and Welsh law is concerned, the central and traditional emphasis on case law and civil liberties. 
These attempts to re-position the UK government on Europe have led to changes in the constellation key actors at the core of UK European policy making. As we have seen the office of Prime Minister and the role of his advisers on Europe have been enhanced. The increase in the size of COES and the raising of the status of its leading officials and its focus on No 10 has extended the Prime Minister's ability to act on matters European. Also Blair's more executive, almost presidential style has meant that the secretariat has been able to speak with more authority to departments. Again this is an addition of resource and clout to the already established position of Prime Minister as lead player in relation to European policy making. A position which has gradually been evolving over the period since the establishment of the European Council in 1976. Also enhanced has been the office of Minister of State Europe, but the significance of this post depends upon the qualities of the incumbent and their relationship with the Prime Minister. Not all the incumbents have had good access to No 10 or have been effective in exploiting the opportunities available to them. In addition, the position of cabinet ministers has been extended, at least so far as engaging with their European counterparts are concerned. The bi-lateral aspect of the Step Change initiative has sought to encourage more regular and purposeful interaction on the part of minister and their European counterparts.

Given these changes in position how have these actors responded? Blair certainly began well on Europe and has sustained a high EU profile. However, over time the gains of increased contact and diplomacy have been compromised by UK reticence over an increasing number of key issues such as joining the EURO and the European Convention. Most significantly UK support for the US led invasion of Iraq has undermined much of the gains made in EU diplomacy and coalition building especially with France and Germany. More broadly the bi-lateral offensive at ministerial level was initially skewed towards France and Germany with 70 and 88 ministerial visits respectively in the year 1999 - 2000. In the following year more was done to exploit contacts with Spain and Belgium (who held the Presidency). Notably the least active core department in terms of ministerial contacts was the Treasury. So the overall picture of the actual exploitation of the opportunities envisaged in the step change programme has been patchy. Moreover, judging by opinion polls, the attempt to educate the public about the facts of Europe has failed to register. Of course, it is essential to recall that the step change initiative is a 10 year project. In the meantime, if we are to generalise, then it is fair to say that so far there significant new opportunities for actors have been created and extra resources put in place, but actual delivery has been limited.

\section{The outer circle of policy makers}

Beyond the inner core of UK European policy makers, the key changes have affected both organisational cultures and the distribution of formal authority. As far as the former is concerned, all departments and government agencies have been asked by the Prime Minster to heighten awareness of European issues across all levels and sections. This is a continuation of previous initiatives all aimed at mainstreaming Europe across central government. There is, however, still no comprehensive overall co-ordinated training and induction programme. This facility still tends to be provided in house and given the policy area specific nature of European business there are good reasons why it should remain so. There is much variation across Departments, but overall the degree of 
European awareness is higher. This is in part a product of the slow 'socialising' effect that increased involvement with the EU has brought into-play over three decades of membership. In part also it is a product of the deliberate post 1997 effort by the Centre to inculcate across the board more awareness of matters European. Amongst departments that have significantly enhanced their engagement has been the Home Office which continues to co-ordinate JHA and has been increasingly drawn in on matters concerning immigration, asylum, and organised crime.

The key change in formal authority affecting the outer circle of UK EU policy makers has been a change in responsibility for all domestic policies that have a significant EU content. Policy development in these areas has, since July 1999, had to accommodate the input of the new authorities established in the devolved territories, especially in Wales and Scotland. Although relations with the EU are reserved to the UK as the member state government, responsibility for implementation of EU requirements falls upon the devolveds within their territories. This has been interpreted as requiring that the devolveds should be involved in the formulation as well as the implementation of policy. This provides the devolved governments with a privileged position in the making of national European policy compared with the English regions and regions in other EU member states. Arguably this represents a shift of authority from central government. In effect the basic structure of the state has been changed creating a potentially more varied interpretation of 'national' European interests and objectives. The consequences of this significant re-ordering of authority is taking time to work through, but is clearly significant both in terms of its potential and actual effect.

In effect devolution marks an end of the UK unitary, centralised state. It raises a whole series of challenges to the centralised and contained character of the established UK/EU policy-making process. In particular, devolution raises questions about the extent to which:-

- The greater political diversity it has created will generate political disputes between central and devolved executives over European policy.

- The extent to which the asymmetric nature of devolution (with differing settlements in Scotland and Wales) have made the procedures for handling European policy more cumbersome and complex.

- The extent to which information sharing has been affected. Have civil servants in Cardiff and Edinburgh remained as well connected with their counterparts in London?

- The extent to which new representational arrangements will be needed for Scotland and Wales in Brussels and with UKRep.

These challenges are working their way through. They imply a substantial and significant alteration in the way the UK conducts European business. They involve shifts in authority, changed veto points and institutional opportunity space, as well as alterations in the organisational and political cultures underlying the development of policy. All of these changes have opened up new opportunities for the articulation and highlighting of subnational interests and for the exercise of agency in further developing the emerging multilevel character of UK governance. 
Nevertheless, while the changes brought about by devolution in institutional structures seem significant, it remains a moot point at this early stage as to whether, how and when the opportunities created by institutional change will be exploited. The potential is there but its exact expression remains to be manifested and that depends on a number of factors that can be enumerated if not predicted. These include changes in party control at any one of Westminster, Edinburgh and Cardiff, and also the emergence of new policy issues with different implications for each of the territories of the UK, and unforeseen events. The critical change centres on the point that pre-devolution UK European policy making took place with a framework of collective responsibility to which ministers were bound. The consequence of this was that tensions that undoubtedly existed between the territories were sorted out within the central state structure. Under devolved arrangements Scottish and Welsh ministers are under greater pressure to make public a distinctive line. In effect devolution opens up the process, introduces new arenas and new points of tension and conflict. These may generate further tension and more significant further change.

Devolution has also given the Welsh and Scottish authorities the opportunity to deploy resources in order to clarify, articulate and pursue in a focussed way the interests of their locality in relation to Europe. Both the Scottish and Welsh authorities have reviewed and expanded their representation in Brussels as well as maintaining involvement with and access to UKRep (see Bulmer, et al, 2002, chapter 6). So far as developing sub-national interests through channels to Whitehall are concerned, continuing involvement in the UK policy process offers opportunities to articulate sub-national views in policy development. Clearly the opportunities are there but the critical point remains as to how and when they will be exploited. So overall the European policy making process in the UK has become less self-contained within the central state as a result of devolution. It opens up new opportunities for territorial governments to play their hand through exploiting both extra-state and intra-state channels.

\section{CONCLUSION}

In general the gradual Europeanisation of central government continued under Labour in response to the on-going expansion of EU activity and the natural build up of connections and understanding that simply being involved in a political and policy making process over a substantial period entails. Now all ministries are involved in diplomacy and go to Europe and do business there. Indeed the European dimension of central government is absolutely essential to understanding how it now operates (Bulmer and Burch 2000) This gradual Europeanisation has had all sorts of side effects. For example, the position of the FCO as the 'overseas' ministry has been eroded; doing business in Europe is now a task it shares with all others in Whitehall. There remains the odd position of the Treasury, but even here there is much more European expertise available even though it is applied within an organisational culture that remains inward looking. So in essence Europeanisation has spread further and deeper across government. This has affected both the content of policy and the practice of policy making. Under Labour this gradual and cumulative pattern of Europeanisation has been accelerated and encouraged by a steady push from the top. 
Beyond the amplification of past trends, there has, however, been a step change in the handling and approach to European policy making under Labour. There are two dimensions to this. First Labour has been able at ministerial level and throughout government to take a more pro-active, directive and strategic approach to Europe. This has been possible because, compared with previous administrations, there have been fewer deep divisions within the leadership over Europe. Consequently strategic considerations concerning Europe have been able to be developed at ministerial level across government without deep discord. Under the Major administration, by contrast, such matters were avoided for fear of dividing the government. So that strategic thinking tended to take place either clandestinely or at official level through various ad hoc devices. These devices still exist, but there is more of a ministerial steer and policy questions have re-verted back to their domain. The second sense in which there has been a step change relates to the structure of policy making. The creation of devolved authorities in Scotland and Wales (and in Northern Ireland) has changed the way the UK process of European policy making works and the pressures brought to bear upon it. In essence the institutional pitch has changed, as have some of the players and the rules of play. How this will play out in practice remains to be seen as tricky issues arise and if and when political control at the sub-national and national level diverges.

Of course the devolution step reflects domestic changes: notably Labour's domestically generated programme of constitutional reform. Though it is noticeable that the multilevel structure that is emerging in the UK is more in keeping with the pre-dominant model of state structures in the EU and chimes with the EU associated idea of a 'Europe of the regions'. Indeed in charting change since 1997, the Europeanising effect is often evident but it seems less important than other factors such as constitutional reform, or the Blair 'style' of governance. The 'step change', bi-lateral programme contains some innovative features which adapt established European ways of working with an emphasis on networking and coalition building. Other Europeanising effects are less direct and primary, though in all instances they are one of the contributory factors glimpsed in the background.

In sum, the machinery, process and the approach to handling Europe has changed, the potential for projecting the UK in Europe is greater than ever before, personnel are more aware and more engaged, and there is leadership and a strategic vision of the UK's place in Europe. If, however, we asked how effective these changes have been in terms of beneficial outcomes then it would be harder to argue that there has actually been a step change. Admittedly we are looking at a ten year project so it is early to judge. In any case measuring the effects of diplomacy and enhanced networking is notoriously difficult. Certainly impact on public attitudes to Europe seems to have been marginal. These still remain a significant drag on any efforts to pursue an innovative and leading approach in Brussels. The veto that has always been applied by a reticent and divided public remains intact. Then there is the impact of the Iraq war on all that has been done thus far so far as alliances and contacts with EU member state counterparts are concerned, while the euro retreat of June 2003 tended to confirm the traditional perception of the UK as a reluctant 
partner. So, has all this amounted to a step change? In approach - yes. In outcome - at least not yet.

\section{REFERENCES}

Baker, D and Seawright, D (1998), eds., Britain For and Against Europe (Oxford: Clarendon Press.

Blair, Tony (2000), Speech to the Polish Stock Exchange, $6^{\text {th }}$ October, www.number10.gov.uk/ (Speeches)

Blair, Tony (2002), 'A Clear Course for Europe', Speech in Cardiff, $2^{\text {nd }}$ December, WwW.number-10.gov.uk/(Speeches)

Börzel, Tanja (1999), “Towards Convergence in Europe? Institutional Adaptation to Europeanization in Germany and Spain”, Journal of Common Market Studies, 39/4: 57396.

Bulmer, Simon (1997), "Shaping the Rules? The Constitutive Politics of the European Union and German Power", in Peter Katzenstein (ed.), Tamed Power: Germany in Europe (Ithaca, NY: Cornell University Press): 49-79.

Bulmer, Simon and Burch, Martin (1998), "Organising for Europe - Whitehall, the British State and the European Union”, Public Administration, 76/4: 601-28.

Bulmer, Simon and Burch, Martin (2000) "The Europeanisation of British Central Government", in R.A.W. Rhodes (ed) Transforming British Government; Volume 1: Changing Institutions (London: Macmillan) 46-62.

Bulmer, Simon and Burch, Martin (2002) "British Devolution and European Policy Making: A Step Change Towards Multi-Level Governance", politique europeenne, 6, 114-136.

Bulmer Simon, Burch Martin, Carter Caitriona, Hogwood Patricia, and Scott Andrew (2002), British Devolution and European Policy-Making: Transforming Britain into Multi-Level Governance (London: Palgrave).

Bulmer, Simon and Radaelli, Claudio (2004 forthcoming), "The Europeanisation of National Policy?", in Simon Bulmer and Christian Lequesne (eds), XXX (Oxford: Oxford University Press). 
Burch, Martin and Gomez, Ricardo (2002), "The English Regions and the European Union" Regional Studies 36/7: 767-778.

Burch, Martin and Gomez, Ricardo (2003), "Europeanization and the English Regions", paper for UACES/ESRC seminar, Sheffield $2^{\text {nd }}$ May.

Burch, Martin and Holliday, Ian (1996), The British Cabinet System (London: Prentice Hall).

Cowles Maria Green, Caporaso James and Risse Thomas (eds.) (2001), Transforming Europe: Europeanization and Domestic Change (Ithaca NY: Cornell University Press).

Fairbrass, Jenny (2003), "The Europeanization of Interest Representation: UK Business and Environmental Interests Compared", paper for UACES Conference, Newcastle, $3^{\text {rd }}$ September.

Featherstone, Kevin and Radaelli, Claudio (eds) (2003), The Politics of Europeanisation (Oxford: Oxford University Press).

Hay, Colin and Rosamond, Ben (2002) "Globalisation, European integration and the discursive construction of economic imperatives", Journal of European Public Policy 9/2: 147-167.

Jordan, A. (2002), The Europeanization of British Environmental Policy. A Departmental Perspective (Basingstoke: Palgrave Macmillan).

Knill, Christoph (2001) The Europeanisation of National Administrations. Patterns of Institutional Persistence and Change (Cambridge: Cambridge University Press).

Naughtie, James (2001), Rivals - Blair and Brown: the Intimate Story of a Political Marriage, (London: Fourth Estate).

Page, Edward (1998), “The impact of European legislation on British public policy making: a research note", Public Administration 76/4:803-9.

Pierson, Paul (1996), "The path to European integration. A historical institutionalist analysis", Comparative Political Studies, 29/2, 123-63.

Radaelli, Claudio (2000), "The Europeanization of Public Policy: Notes on Theory, Methods and the Challenge of Empirical Research", European Integration on-line paper (http://www.eiop.or.at).

Risse, Thomas, Cowles, Maria Green, and Caporaso, James (2001), "Europeanization and Domestic Change: Introduction”, in Cowles, Caporaso and Risse, pp. 1-20. 
Smith James (2001), "Cultural Aspects of Europeanisation: The Case of the Scottish Office”, Public Administration, 79/1, 147-65.

Smith Martin (1999), The Core Executive in Britain (London: Macmillan).

Thain, Colin and Wright, Maurice (1995), The Treasury and Whitehall (Oxford: Oxford University Press).

Wallace, Helen (2001), "One Europe or Several", paper and presentation at the European Community Studies Association biennial conference, Madison, Wisconsin.

Wallace, Helen and Wallace, William (1973), "The impact of Community membership on the British machinery of government", Journal of Common Market Studies XI: 24362.

Young, John (2000), Britain and European Unity 1945-1999, second edition, (London: Macmillan). 


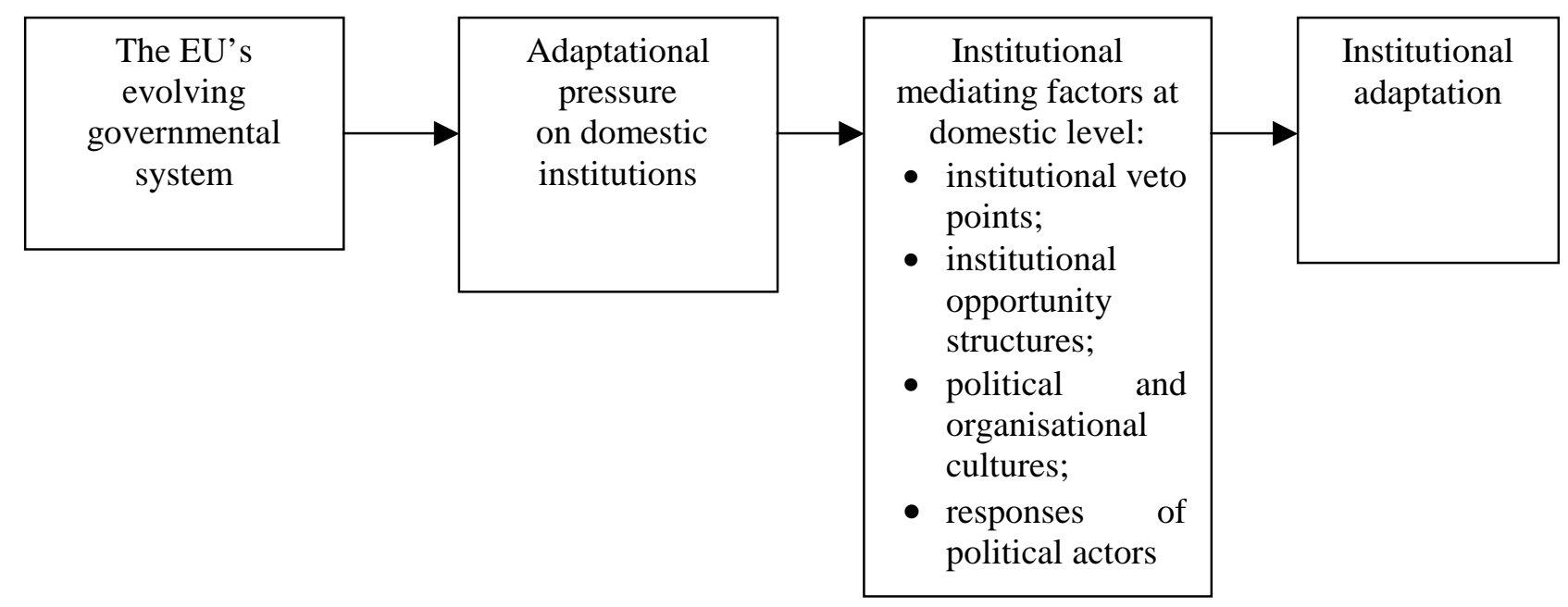

Figure 1: Europeanization and institutional adaptation

Note: this figure is modified and simplified from Figure 1.1 of Risse, Cowles and Caporaso (2001: 6).

\footnotetext{
${ }^{1}$ This paper is based on three research projects funded by the UK's Economic and Social Research Council. The first, conducted by Bulmer and Burch, ... The second, "Devolution and European PolicyMaking in Britain", was funded by Award L327 25 3024, under the ESRC programme Devolution and Institutional Change and ran from March 1999-April 2000. The third, "Asymmetric Devolution and European Policy in the UK" is funded by Award L 219252003 and runs from October 2001-May 2004. We acknowledge the ESRC's support. We are also grateful for the fruitful exchanges with our co-researchers on devolution: Caitriona Carter, Ricardo Gomez, Patricia Hogwood and Andrew Scott.

${ }^{2}$ The unadapted definition from Bulmer and Radaelli (forthcoming 2004) is more top down than the one used here. The original is below; we have removed two words as indicated in italics.

Europeanisation consists of processes of a) construction, b) diffusion and c) institutionalisation of formal and informal rules, procedures, policy paradigms, styles, "ways of doing things" and shared beliefs and norms which are first defined and consolidated in the EU policy process and then incorporated in the logic of domestic (national and subnational) discourse, political structures and public policies.

${ }^{3}$ As Page notes, EU activity in some policy areas, notably Justice and Home Affairs or foreign policy, is not by means of legislation, so the impact in these domains is not captured in his statistics (Page 1998: 808).

${ }^{4}$ For a review of German congruence with the EU system, see Bulmer (1997). It is worth pointing out that this apparent congruence has not led to the federal government being considered an especially effective negotiator in the EU, i.e. in terms of "projection".

${ }^{5}$ Interview with MoD official.
} 